\title{
Análisis de envejecimiento en paneles sándwich de madera
}

\section{Ageing tests study on wood-based sandwich panels}

\author{
$\underline{\text { R. Mateo }}^{(*)}$, J. C. Cabrero(**), E. Hermoso(**), J. M. Chillón(***)
}

Recepción/Received: 24-III-10

Aceptación/Accepted: 11-X-10

Publicado online/Online publishing: 25-XI-10

\section{RESUMEN}

Los paneles sándwich de madera son un producto de creciente aplicación en la edificación de nuestro país. Este ascendente uso del material debe estar acompañado de las garantías necesarias avaladas por un estudio previo de sus prestaciones. Como es preceptivo y entre otros, se evalúa su durabilidad frente a las condiciones climatológicas, clave en los productos derivados de la madera, acorde a la normativa actual definida con tal fin, la Guía ETAG 016. Sin embargo, debido a la clase de uso del material, se ha detectado que dicha normativa tal y como está concebida no es capaz de valorar su envejecimiento adecuadamente. En este trabajo se proponen ensayos alternativos al establecido tras exhaustivos análisis que recrean las condiciones reales de uso y más acordes a los productos de madera. Se concluye que la incorporación de una lámina impermeable, pero permeable al vapor de agua hacia el exterior, como las utilizadas en el montaje, aportan el mejor procedimiento de ensayo.

Palabras clave: paneles sándwich, madera, envejecimiento, durabilidad, ciclos climáticos.

\section{SUMMARY}

Composite lightweight wood panels are being increasingly used in construction in Spain. Their growing use should be accompanied by necessary guarantees based on studies of their properties. As it is prescriptive and in addition to others tests, in the present work is examinated the durability of these panels when exposed to the climatic conditions, a characteristic of great importance for wood products, according to Guide ETAG 016, the current standard defining the ageing tests to be used. However, due to the use class of this material, there are indications that the testing outlined in this Guide is inappropriate for assessing the ageing of woodbased sandwich panels. Alternative tests are here proposed that recreate rather better the real conditions under which these products are used. Covering the samples in a waterproof sheeting permeable to the outward movement of water vapour, which is in fact used in the installation, provided the best procedure for testing these panels.

Keywords: wood-based sandwich panels, wood, ageing, durability, climatic cycles.

(*) AITIM (Unidad Conjunta INIA-AITIM) (Madrid, España).

(**) CIFOR-INIA (Madrid, España).

(***) Instituto de Ciencias de la Construcción Eduardo Torroja (IETcc-CSIC) (Madrid, España). 


\section{INTRODUCCIÓN}

Los paneles sándwich son productos industriales que están compuestos, generalmente, por tres capas: dos paramentos unidos por un alma o núcleo aislante mediante encolado, habitualmente con adhesivos termofusibles de poliuretano en el caso de aislantes como el poliestireno extruido.

El uso de este producto se ha extendido en los últimos años debido a sus buenas propiedades de ligereza, aislamiento y resistencia, además de aportar el acabado final a la estructura y facilidad de instalación. Por esta razón ha incrementado su uso en edificaciones como polideportivos, piscinas cubiertas, grandes superficies, etc., lo que requiere de un control de calidad exhaustivo que dé garantías al usuario final.

Desde hace varios años, la Unidad Conjunta INIA-AITIM colabora con el Instituto de Ciencias de la Construcción Eduardo Torroja (IETCC), para la obtención del Documento de Idoneidad Técnica Europeo (DITE) por parte de fabricantes de paneles sándwich autoportantes, vía que se aplica para alcanzar el marcado CE $(1,2)$.

La caracterización de este tipo de productos autoportantes se ajusta a la Guía ETAG-016 (European Technical Approvals Guide) (3), publicada por la Organización EOTA (4). La Unidad Conjunta INIA-AITIM lleva realizando desde hace más de tres años la parte de los ensayos mecánicos contemplados en dicha Guía y entre ellos se incluye la prueba de envejecimiento mediante la aplicación de ciclos climáticos. Este ensayo, concebido tal y como establece la ETAG-016, está encaminado a evaluar cualquier tipo de panel autoportante sin tener en cuenta el modo de instalación o la composición del mismo.

Los paneles de madera o derivados de la madera están concebidos para su utilización según la clase de uso 2 que define el Código Técnico de la Edificación (5), es decir, instalados bajo cubierta protegidos de la intemperie aunque ocasionalmente se pueda dar un contenido de humedad mayor que el $20 \%$ en parte o en la totalidad del elemento. Sin embargo, el ensayo actualmente definido en la Guía establece condiciones propias de una clase de uso 3, es decir, como si el material se instalase al descubierto y sometido a una humidificación frecuente. Según esta razón, realizando el ensayo tal como establece la metodología, el tablero de partículas que compone el paramento exterior queda en un estado tan degradado que resulta muy difícil ensayar el conjunto y en caso de ser posible, se obtienen unas tensiones de fallo muy bajas. Esto es una consecuencia de haber

\section{INTRODUCTION}

Wood-based sandwich panels are industrial products generally composed of three layers: two outer faces each glued to an insulating middle layer. When this insulating material is extruded polystyrene (XPS) the glue used is usually a thermosetting polyurethane adhesive.

The use of these panels has become more widespread in recent years, owing to their low weight, insulating properties and resistance, the possibility of using them as the finishing layer of structures, and the ease with which they can be installed. These advantages had encouraged their use in the construction of sports centres, covered swimming pools and shopping centres, etc. However, such use demands exhaustive quality control if end-users are to be afforded appropriate guarantees.

For some years now, the Unidad Conjunta INIA-AITIM (the INIA-AITIM Joint Unit) has been collaborating with the Instituto de Ciencias de la Construcción Eduardo Torroja (IETCC; Eduardo Torroja Institute for Construction Sciences) in order to produce an European Technical Approval (ETA) document for use by manufacturers of wood-based sandwich panels, the route to be followed for the approval of CE marking $(1,2)$.

The characterisation of this type of product is outlined in Guide ETAG 016 (European Technical Approval Guide 016) (3), published by the European Organisation for Technical Approvals (EOTA) (4). The INIA-AITIM Joint Unit has for three years undertaken the mechanical testing contemplated in the above guide; this includes testing involving the ageing of samples in climatic testing cycles. The methodology established by Guide ETAG 016 is designed for the assessment of all kinds of self-supporting composite panels irrespective of their composition or the manner in which they are installed.

The wood-based sandwich panels, are prepared for their utilization in use class 2 according to the Technical Building Code (CTE) (5) of Spain, in which they are installed covered and protected from the outdoors, though occasionally there could give them a content of greater moisture content that $20 \%$ in part or in the totality of the element. However, the test nowadays defined in the Guide establishes conditions of use class 3 , as if the material was installed to the outdoors and submitted to a frequent humidification. Therefore, conducting the test as required by the methodology, the external faces, of which are generally made of chipboard, this test is too aggressive. In fact, if the standard methodology is followed, these chipboards can become so deteriorated that it is very hard to test the panel as a complete unit at all, and when it is possible, 
adoptado el ensayo ya existente para paneles metálicos (UNE-EN 14509) (6), material de instalación y propiedades muy diferentes frente a la humedad.

La madera es un material higroscópico, es decir, es capaz de absorber y eliminar agua hasta equilibrarse con el ambiente que le rodea. Por este motivo, el tablero de partículas que generalmente forma el paramento exterior del panel, sometido a unas condiciones del $100 \%$ de humedad (como establece el ensayo), tenderá a equilibrarse y a aumentar su humedad hasta la saturación. Además, las colas que unen las partículas de madera en un tablero son hidrosolubles y al estar en contacto con un ambiente húmedo y altas temperaturas provocan la pérdida de cohesión de las partículas, es decir, el tablero pierde su estructura y, por tanto, sus propiedades mecánicas (7-9).

Pese a que no se han encontrado referencias bibliográficas sobre estudios relacionados con la durabilidad frente a condiciones ambientales para este tipo de paneles, la importancia de conocer este comportamiento de la madera y de sus productos derivados queda patente en los numerosos trabajos publicados y en la normativa desarrollada para su evaluación. Desde antiguo ha constituido una inquietud el estudio de la metodología empleada para evaluar el envejecimiento de la madera (10), pero actualmente todavía se trabaja sobre la evaluación del comportamiento frente a la humedad en distintos productos de madera como tableros (OSB, contrachapado, MDF, etc.) 11-14, madera de distintas especies (15, 16), sobre el efecto de la protección de tableros o madera mediante recubrimientos o modificando su estructura $(17,18)$ y sobre el análisis del deterioro que se produce en la estructura del material (19).

Ante la dificultad de realización del ensayo de ciclos climáticos tal y como establece la Guía ETAG-016 en paneles sándwich compuestos por madera o derivados de la madera, y teniendo en cuenta que la instalación final no queda en clase de uso 3 como en el caso de los metálicos, surge la idea de estudiar una modificación del ensayo que valore la situación real de uso y se adecúe a la clase de uso 2.

\section{MATERIALES Y MÉTODOS}

La influencia del envejecimiento en los paneles o en sus componentes se cuantifica en la variación de la tensión de fallo a tracción tras la aplicación del ciclo de durabilidad correspondiente.

Este trabajo se centra en el ensayo de paneles con núcleo de poliestireno extruido (XPS), aunque también very low tensile strengths are recorded. The problem lies in Guide ETAG 016 having adopted the test for metallic panels UNE-EN 14509 (6); metallic panels would, of course, behave very differently when exposed to moisture and also their installation is distinct.

Wood is a hygroscopic material, i.e., it absorbs or eliminates water until reaching the equilibrium moisture content according to its surrounding environment. Thus, when subjected to $100 \%$ humidity (required by the test), the moisture in the chipboard exterior face of these panels tends to increase in order to reach this equilibrium. Unfortunately, the adhesives used to glue the particles together are water-soluble, so in humid and high temperature environments, a loss of cohesion between particles occurs. The board therefore disintegrates and loses its mechanical properties (7-9).

Although they have not found bibliographical references on the durability to weathering of these panels as complete units, the need to understand the behaviour of wood and wood-based products is made patent in the numerous reports available in this area, and in the standards developed for their assessment. There have long been concerns regarding the methodology employed to assess the ageing of wood (10), although the effect of moisture on different wood products, such as OSB, plywood and MDF, etc. (11-14), and different species of wood $(15,16)$, has received research attention. Work has also been undertaken to determine the effect of protecting boards or lumber with coverings or by modifying their structures $(17,18)$, and analyses made into the failing of their structure (19).

Given the difficulty of subjecting wood-based sandwich panels to the climatic testing cycles established in Guide ETAG 016, and bearing in mind that when finally installed they are not exposed in use class 3 as are metal panels, the aim of the present work was to study a number of modifications to the standard test that might better reflect their real conditions of use class 2.

\section{MATERIALS AND METHODS}

The influence of ageing on the panels and their components was examined via the changes recorded in their tensile strength after their subjection to climate testing cycles.

The present work focuses on panels with an XPS nucleus, although some samples with an injected 
se evalúa alguna muestra con poliuretano inyectado para observar las diferencias. Para paneles con alma de poliestireno extruido, el ciclo que establece la Guía ETAG-016 consiste en introducir las muestras en una cámara a las condiciones constantes de temperatura del aire de $65 \pm 3{ }^{\circ} \mathrm{C}$ y humedad relativa del $100 \%$. Estas condiciones se deben conseguir calentando agua en el fondo de la cámara, creando una atmósfera a la temperatura y humedad indicadas en las que se situarán las probetas, sin estar en contacto con el agua.

La norma también define que un conjunto de muestras deben someterse a las condiciones anteriormente descritas durante siete días. Después del ciclo se almacenan en condiciones de laboratorio $\left(20-25{ }^{\circ} \mathrm{C}\right.$ de temperatura y $40 \%$ de humedad relativa) hasta que se estabilice la masa, momento en el cual se ensayan a tracción obteniéndose una tensión de fallo en $\mathrm{N} / \mathrm{mm}^{2}$ denominada R7. Otro conjunto de probetas se someten al mismo ciclo pero durante 28 días, se almacenan en condiciones de laboratorio hasta estabilizar la masa y se ensayan a tracción obteniéndose una tensión R28. Si los resultados de los ensayos muestran una tendencia descendente en la tensión de fallo con el tiempo, se realizará el ciclo a otro conjunto de probetas sometiéndolo a las condiciones establecidas esta vez durante 56 días, obteniéndose la tensión R56.

Los ensayos de resistencia a tracción efectuados tras los ciclos según ETAG-016 para valorar la capacidad estructural del panel envejecido, se realizan en una máquina universal. Antes, las superficies deben prepararse con un lijado y luego se encolan a los útiles de tracción. Después se dejan estabilizar durante 24 horas antes del ensayo.

Sin embargo, esta metodología trata de valorar la realidad bajo las condiciones normales de uso de los paneles, y el procedimiento descrito no es válido al producir un total deterioro de las muestras tras los ciclos que impiden la finalización del ensayo mediante la resistencia a la tracción. Buscando vías alternativas, se realizan los siguientes ensayos.

\subsection{Ensayos en probetas barnizadas}

Se realiza la evaluación de la durabilidad de paneles sándwich tras ciclos de siete días en las condiciones que establece la ETAG-016 pero aplicando a los tableros derivados de la madera un barniz aislante de la marca Xylacel, tanto en el paramento como en los cantos, de forma que se limite la entrada de humedad y por tanto no sea tan agresivo el ensayo. Se las deja secar durante 24 horas antes de introducirlas en la cámara. Tras el ciclo, se procede a la prueba de tracción conforme ETAG 016. En la Tabla 1 se muestra el polyurethane (PUR) nucleus were also tested for the sake of comparison. For the former, the climatic testing cycles established by Guide ETAG 016 require samples be introduced into a chamber with an air temperature of $65 \pm 3{ }^{\circ} \mathrm{C}$ and a relative humidity of $100 \%$. These conditions were attained by heating water at the bottom of the chamber. The test samples are then introduced into the chamber making sure that they did not come into direct contact with the water.

In addition, the standard defines that some panel samples be subjected to the temperature and humidity conditions described above for seven days. After this time they are stored under laboratory environment (temperature $20-25{ }^{\circ} \mathrm{C}, 40 \%$ relative humidity) until their mass stabilizes. Then, the samples are subjected to a tensile strength test, the results of which ( $R 7)$ are expressed in $\mathrm{N} / \mathrm{mm}^{2}$. Other samples are subjected to a 28 day climatic testing cycle before storage as above until their mass stabilizes and the tensile strength tests performed (R28). If the results show a decreasing trend in tensile strength, samples are subjected to another climate cycle but for 56 day (R56).

After the above ageing procedures, the samples underwent the tensile strength test prescribed in ETAG 016. The surfaces were first sanded before being glued to the plates of a universal testing machine. All samples were left for 24 hours before inducing tension.

However, the above methodology is not well adjusted for use with wood-based sandwich panels. The present work therefore, try to assess these panels under more normal conditions of their use and the analysis of the researches about the best test, are reported.

\subsection{Ests of varnish-protected wood-based sandwich samples}

Some samples underwent the seven-day climatic testing cycle outlined above after applying one coat of insulating Xylacel, varnish to their faces and edges. This limited the entry of moisture, reducing the aggressiveness of the test conditions. Table 1 shows the characteristics of the varnished samples, all of which had a nucleus $40 \mathrm{~mm}$ thick. All samples thus treated were left to dry for $24 \mathrm{~h}$ before being placed in the chamber. All samples were 
número, tipo y dimensiones de las probetas, todas con espesor del núcleo de $40 \mathrm{~mm}$. then tested for their tensile strength according to ETAG 016.

Tabla 1 / Table 1

Material utilizado para el ensayo de envejecimiento con aplicación de barniz. Characteristics of the varnish-coated samples tested.

\begin{tabular}{|c|c|c|}
\hline Probeta / Sample & Tipo de panel / Type of panel sample & Dimensiones / Dimensions (mm) \\
\hline PR1 & Partículas-XPS-friso de abeto / Chipboard-XPS-Fir baseboard & $70 \times 70 \times 66$ \\
\hline PR2 & Partículas-XPS-friso de abeto / Chipboard-XPS-Fir baseboard & $70 \times 70 \times 66$ \\
\hline PR3 & Partículas-XPS-madera cemento / Chipboard-XPS-Cement wood board & $100 \times 100 \times 66$ \\
\hline PR4 & Partículas-XPS-madera cemento / Chipboard-XPS-Cement wood board & $100 \times 100 \times 66$ \\
\hline PR5 & Partículas-XPS-contrachapado / Chipboard-XPS-Plywood & $100 \times 100 \times 66$ \\
\hline PR6 & Partículas-XPS-contrachapado / Chipboard-XPS-Plywood & $100 \times 100 \times 66$ \\
\hline
\end{tabular}

\subsection{Ensayos en tableros de partículas hidrófugos P3 y P5}

Debido a que una de las principales causas del fallo de los paneles tras la aplicación de ciclos de envejecimiento, y posteriormente el ensayo a tracción, se producía en el tablero de partículas, hizo pensar que su calidad podría ser determinante en los resultados que se obtuvieran ya que en la mayoría de los casos constituye el paramento exterior del panel sándwich. Por este motivo se realizan ensayos sobre tableros P3 y P5, resistentes a la humedad según UNE-EN 312 (20), siguiendo la Guía ETAG-016 para de esta forma analizar la conveniencia del uso de uno u otro tipo como componentes de los paneles. El número de probetas ensayadas se muestran en la Tabla 2.

\subsection{Tests of $P 3$ and $P 5$ waterproof chipboard}

One of the main causes of failure of wood-based sandwich samples in tensile strength tests following their subjection to climatic testing cycles is the deterioration of the external chipboard face. Thus, the quality of the chipboard used may influence the tensile strength results obtained. Tests were therefore performed on P3 and P5 boards, which are waterproof according to UNE-EN 312 (20), following ETAG 016, in order to determine whether one or the other was more suited for use in such panels. Table 2 shows the number and characteristics of the samples tested.

Tabla 2 / Table 2

Probetas para el ensayo de envejecimiento en tableros P3 y P5. $P 3$ and P5 waterproof chipboard face analysed.

\begin{tabular}{|c|c|c|c|}
\hline Tipo de panel / Type of panel & Probeta / Sample & Espesor / Thickness & $\begin{array}{c}\text { Duración del ciclo (días) I } \\
\text { Climatic testig cycle time (days) }\end{array}$ \\
\hline \multirow{10}{*}{ P3 } & P3-1-1 & 21 & 7 \\
\hline & P3-1-2 & 21 & 7 \\
\hline & P3-1-3 & 21 & 7 \\
\hline & P3-1-4 & 21 & 28 \\
\hline & P3-1-5 & 21 & 28 \\
\hline & P3-2-1 & 16 & 28 \\
\hline & P3-2-2 & 16 & 28 \\
\hline & P3-2-3 & 16 & 28 \\
\hline & P3-2-4 & 16 & 7 \\
\hline & P3-2-5 & 16 & 7 \\
\hline \multirow{10}{*}{ P5 } & P5-1-1 & 19 & 7 \\
\hline & P5-1-2 & 19 & 7 \\
\hline & P5-1-3 & 19 & 7 \\
\hline & P5-1-4 & 19 & 28 \\
\hline & P5-1-5 & 19 & 28 \\
\hline & P5-2-1 & 16 & 28 \\
\hline & P5-2-2 & 16 & 28 \\
\hline & P5-2-3 & 16 & 28 \\
\hline & P5-2-4 & 16 & 7 \\
\hline & P5-2-5 & 16 & 7 \\
\hline
\end{tabular}


Una vez terminado el ciclo correspondiente, se evalúan las probetas mediante la prueba de tracción.

\subsection{Ensayos de envejecimiento con variación de la duración del ciclo}

Puesto que las condiciones a las que se somete la madera son demasiado agresivas y permanentes durante un tiempo extenso, se trata de evaluar cómo afecta al panel cada día de ciclo que pasa hasta completar una semana. De esta forma se pretende comprobar la reducción progresiva diaria del fallo a tracción que se produce. En este análisis se estudiaron fabricantes diferentes y distintas tipologías de panel para comprobar la independencia de los resultados. De cada tipología se someten a ciclos siete probetas, cada una de ellas destinada a una duración; estas se introducen a la vez y se extrae de la cámara una cada 24 horas, hasta completar los siete días. La tipología y fabricante de las probetas se muestran en la Tabla 3.
After the corresponding cycle, the specimens were evaluated by tensile strength test.

\subsection{Samples subjected to different climatic testing cycle times}

Since the conditions to which the samples were subjected were aggressive, daily checks were made to determine the effect on the sandwich panel up to a climatic testing cycle time of seven days. The aim was to follow the daily reduction in tensile strength. This analysis involved different types of samples as well as samples made by different manufacturers (see Table 3) to verify the independence of the results. Seven samples of each were subjected to the climatic testing cycle, one of them being extracted every $24 \mathrm{~h}$ for analysis.

Tabla 3 / Table 3

Características de las muestras expuestas a la variación de la duración del ciclo de envejecimiento. Characterisitics of the samples exposed to different climatic testing cycle time.

\begin{tabular}{|c|c|c|}
\hline Fabricante IManufacturer & Tipo de panel / Type of panel sample & Dimensiones / Dimensions (mm) \\
\hline \multirow{5}{*}{ a F1 / M1 } & Partículas-XPS-madera cemento / Chipboard-XPS-Wood-cement & $100 \times 100 \times 66$ \\
\hline & Partículas-XPS-partículas / Chipboard-XPS-Chipboard & $100 \times 100 \times 66$ \\
\hline & Partículas-XPS-contrachapado / Chipboard-XPS-Plywood & $100 \times 100 \times 66$ \\
\hline & Partículas-XPS-yeso / Chipboard-XPS-Plaster board & $100 \times 100 \times 66$ \\
\hline & Partículas-XPS-friso / Chipboard-XPS-Baseboard & $70 \times 70 \times 96$ \\
\hline F2 / M2 & Contrachapado-XPS-contrachapado/ Plywood-XPS-Plywood & $70 \times 70 \times 70$ \\
\hline \multirow{4}{*}{ a F3 / M3 } & Partículas-XPS-friso / Chipboard-XPS-Baseboard & $70 \times 70 \times 66$ \\
\hline & Partículas-XPS-madera cemento / Chipboard-XPS-Wood-cement & $100 \times 100 \times 66$ \\
\hline & Partículas-XPS-yeso / Chipboard-XPS-Plaster board & $100 \times 100 \times 66$ \\
\hline & Partículas-XPS-Magnesita / Chipboard-XPS-Magneite & $100 \times 100 \times 66$ \\
\hline
\end{tabular}

a F1-F3 se refiere a los fabricantes 1 al 3 / a M1-M3 refer to manufacturers 1 to 2 .

Una vez fuera de la cámara, el procedimiento de ensayo es el descrito anteriormente: permanecen en condiciones de laboratorio hasta que se estabilice la masa y se realiza la prueba de tracción.

\subsection{Determinación de la resistencia a la humedad según UNE-EN 321}

Existe normativa (UNE-EN 321) (21) establecida para la evaluación del comportamiento de los tableros derivados de la madera en condiciones de humedad, por lo que se estudió la posibilidad de que fuera también de aplicación para la valoración de paneles sándwich.

Según dicha norma, las probetas de tablero se someten a tres ciclos, incluyendo cada uno de ellos inmersión en agua, congelación y secado a alta temperatura. Después
Following their removal from the chamber, all samples underwent the standard steps.

\subsection{Determination of moisture resistance in accordance with standard UNE-EN 321}

Standard UNE-EN 321 (21) establishes the conditions for assessing the behaviour of wood-based boards under humid conditions. Its applicability to wood-based sandwich panels was also tested.

According to this standard, panel samples must be subjected to three moisture cycles, including immersion in water in each, freezing, and drying at high 
se acondicionan a una humedad relativa de $65 \pm 5 \%$ y a una temperatura de $20 \pm 2{ }^{\circ} \mathrm{C}$, y se determina la hinchazón en grosor y la resistencia residual. Se consideró suficiente la realización de dos de los tres ciclos para las necesidades de este trabajo, evaluando posteriormente la resistencia a tracción. Las probetas a ensayar se muestran en la Tabla 4. temperature. Test samples are then left in an environment at $20 \pm 2{ }^{\circ} \mathrm{C}$ and $65 \pm 5 \%$ relative humidity, and their swelling and residual resistance determined. Two or three moisture cycles were deemed sufficient for the needs of the present work. Table 4 shows the characteristics of the samples tested.

Tabla 4 / Table 4

Muestras utilizadas para el ensayo de ciclos según UNE-EN 321.

Samples used in the cycling test performed according to UNE-EN 321.

\begin{tabular}{|c|c|c|}
\hline Probeta / Sample & Tipo de panel / Type of panel sample & Dimensiones / Dimensions (mm) \\
\hline CF-40-C2-1 & Partículas-XPS-Friso de abeto / Chipboard-XPS-Fir baseboard & $70 \times 70 \times 66$ \\
\hline CF-40-C2-2 & Partículas-XPS-Friso de abeto / Chipboard-XPS-Fir baseboard & $70 \times 70 \times 66$ \\
\hline CCM-40-C2-1 & Partículas-XPS-maderacemento / Chipboard-XPS-Wood cement & $100 \times 100 \times 66$ \\
\hline
\end{tabular}

\subsection{Ensayo de envejecimiento con lámina Tyvek $\circledast$}

Estas pruebas se realizan en las mismas condiciones que establece la Guía ETAG-016 pero aplicando el ciclo de envejecimiento de un día, dos días y una semana de duración. Se busca recrear las mismas condiciones de instalación que efectúan los fabricantes, es decir, cubiertas con

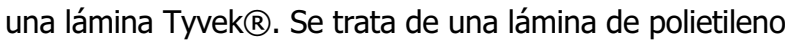
de alta densidad que proporciona alta permeabilidad al vapor de agua hacia el exterior e impermeabilizante hacia el interior, proporcionando un secado rápido a los componentes húmedos. Las probetas utilizadas para este ensayo aparecen reflejadas en la Tabla 5.

\subsection{Ageing tests involving Tyvek® sheeting}

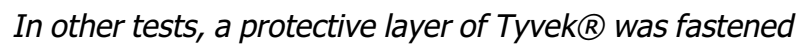
to the outer face of the test samples, as might be used

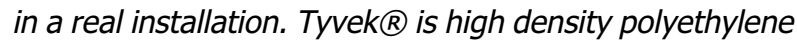
sheeting of great permeability to outward-flowing water vapour, but which shows high impermeability to inward flowing moisture. Damp components therefore dry quickly. Table 5 shows the characteristics of the samples used. In these tests, the climatic testing cycle was performed following that indicated in Guide ETAG 016, but using a period of one day, two days or seven days duration.

Tabla 5 / Table 5

Probetas para el ensayo de envejecimiento con Tyvek $囚$.

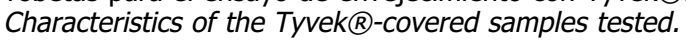

\begin{tabular}{|c|c|c|c|c|}
\hline Probeta / Sample & Tipo de panel / Type of panel sample & $\begin{array}{c}\text { Dimensiones / } \\
\text { Dimensions (mm) }\end{array}$ & $\begin{array}{c}\text { Lámina Tyvek® / } \\
\text { Tyvek® sheet }\end{array}$ & $\begin{array}{c}\text { Duración del ciclo / } \\
\text { Climatic testing } \\
\text { cycle time }\end{array}$ \\
\hline a F1 / M1-P1-C1 & \multirow{4}{*}{ Partículas-PUR-friso de abeto / Chipboard-PUR-Fir baseboard } & \multirow{4}{*}{$70 \times 70 \times 73$} & Sí / Yes & 1 día / 1 day \\
\hline $\mathrm{F} 1 / \mathrm{M} 1-\mathrm{P} 2-\mathrm{C} 2$ & & & Sí / Yes & 2 días / 2 days \\
\hline F1 / M1-P3-C7 & & & Sí / Yes & 7 días / 7 days \\
\hline F1 / M1-P4-C7 & & & No / No & 7 días / 7 days \\
\hline $\mathrm{F} 1 / \mathrm{M} 1-\mathrm{P} 5-\mathrm{C} 1$ & \multirow{4}{*}{ Partículas-XPS-friso de abeto / Chipboard-XPS-Fir baseboard } & \multirow{4}{*}{$70 \times 70 \times 60$} & Sí / Yes & 1 día / 1 day \\
\hline $\mathrm{F} 1 / \mathrm{M} 1-\mathrm{P} 6-\mathrm{C} 2$ & & & Sí / Yes & 2 días / 2 days \\
\hline F1 / M1-P7-C7 & & & Sí / Yes & 7 días / 7 days \\
\hline F1 / M1-P8-C7 & & & No / No & 7 días / 7 days \\
\hline $\mathrm{F} 1 / \mathrm{M} 2-\mathrm{P} 1-\mathrm{C} 1$ & \multirow{4}{*}{ Partículas-XPS-partículas / Chipboard -XPS- Chipboard } & \multirow{4}{*}{$100 \times 100 \times 65$} & Sí / Yes & 1 día / 1 day \\
\hline a F2 / M2-P2-C2 & & & Sí / Yes & 2 días / 2 days \\
\hline F2 / M2-P3-C7 & & & Sí / Yes & 7 días / 7 days \\
\hline $\mathrm{F} 2$ / M2-P4-C7 & & & No / No & 7 días / 7 days \\
\hline $\mathrm{F} 2$ / M2-P5-C1 & \multirow{4}{*}{ Partículas-XPS-contrachapado / Chipboard -XPS-plywood } & \multirow{4}{*}{$100 \times 100 \times 65$} & Sí / Yes & 1 día / 1 day \\
\hline F2 / M2-P6-C2 & & & Sí / Yes & 2 días / 2 days \\
\hline F2 / M2-P7-C7 & & & Sí / Yes & 7 días / 7 days \\
\hline F2 / M2-P8-C7 & & & No / No & 7 días / 7 days \\
\hline
\end{tabular}

a F1 y F2 se refiere al fabricante 1 y al 2 / a M1 and M2 refer to manufacturers 1 and 2. 
La preparación de las probetas que llevan lámina se efectúa fijándola al núcleo aislante mediante grapado, tratando de que quede completamente cubierto el paramento exterior. El paramento inferior se cubre de la misma manera con un plástico semirrígido para evitar que se deteriore, ya que en condiciones de uso tampoco recibiría la humedad directamente. Tras el ciclo correspondiente, se retira la lámina y se ensayan a tracción.

\section{RESULTADOS Y DISCUSIÓN}

\subsection{Envejecimiento en probetas barnizadas}

En la Tabla 6 se pueden observar los resultados obtenidos de este ensayo.

A la salida de la cámara de durabilidad, las probetas se presentan muy degradadas $y$, aunque se logran ensayar a tracción, el paramento exterior queda demasiado dañado para asegurar un buen encolado a los útiles que permita un ensayo adecuado.

De los resultados se deriva que no existe regularidad en la tensión de fallo entre probetas del mismo tipo de panel sándwich y no demuestra que el barniz aplicado a las probetas aporte una impermeabilización tal que aumente la resistencia a tracción y permita valorar la durabilidad del panel. Sin embargo, hay una excepción. En el tipo friso se obtiene una diferencia de la tensión de fallo entre las probetas sin barnizar y las barnizadas de un $90 \%$, a favor de las barnizadas, lo que indica que los estudios debían seguir encaminándose a la búsqueda de una impermeabilización adecuada.
The Tyvek, was spread over the outer face board of the samples, stapling the overlap to the sideward-facing insulating nucleus. The inner face was covered in a similar manner with a semi-rigid plastic to prevent its deterioration since, under real conditions, it would not receive moisture directly. After the corresponding climatic testing cycle, the Tyvek, sheet was removed and the samples were subjected to the tensile strength test.

\section{RESULTS AND DISCUSSION}

\subsection{Ageing of varnished samples}

Table 6 shows the results obtained for the panel samples with the varnished chipboard external face.

After their removal from the chamber the samples were very deteriorated. Although the tensile strength test could be performed, the outer face of the sample was too damaged to ensure good adhesion to the test machine's device.

No regularity was seen with respect to the post climatic testing cycle tensile strength of the same types of sample. Varnishing appeared to provide no waterproofing capable of increasing the tensile strength sufficiently to allow the test to be adequately completed, except with the baseboard-type. The varnished baseboard samples showed greater tensile strengths than non-varnished baseboard samples (significant difference was seen at the $90 \%$ level). This result indicates that further studies were required in the way to find a suitable waterproofing.

Tabla 6 / Table 6

Resultados del ensayo de tracción tras la envejecimiento en probetas barnizadas. Tensile strength results of varnish panels.

\begin{tabular}{|c|c|}
\hline Tipo de panel / Type of panel sample & $\begin{array}{c}\text { Valor medio de la resistencia a la tracción / } \\
\text { Mean tensile strength }\left(\mathbf{N} / \mathbf{m m}^{2}\right)\end{array}$ \\
\hline Partículas-XPS-friso / Chipboard-XPS-Baseboard & 0.042 \\
\hline Partículas-XPS-madera cemento / Chipboard-XPS-Wood cement & 0.011 \\
\hline Partículas-XPS-contrachapado / Chipboard-XPS-Plywood & 0.060 \\
\hline
\end{tabular}

a En todos los resultados la incertidumbre de los resultados es igual o menor a 0,001 N/mm² / In all results the uncertainly is $\leq 0.001 \mathrm{~N} / \mathrm{mm}^{2}$.

\subsection{Resultados en tableros P3 y P5}

En la Tabla 7 se presentan únicamente los datos obtenidos del ciclo de siete días.

Las probetas se presentan completamente degradadas y, aunque se logran ensayar, se rompen a nivel de la primera capa de partículas que queda junto al accesorio de ensayo (véase Figura 1).

\subsection{Tensile strength results for the $P 3$ and $P 5$ chipboard}

Table 7 shows the results obtained after the seven-day climatic testing cycle.

The samples appeared to be completely deteriorated, and although the tensile strength test was possible the boards broke at the level of the top layer of particles, the brokenoff pieces remaining stuck to the test device (Figure 1). 
Tabla 7 / Table 7

Resultados de los ensayos de tracción tras envejecimiento en tableros P3 y P5. Tensile strength of P3 and P5 chipboard face.

\begin{tabular}{|c|c|c|}
\hline Tipo tablero / Type of chipboard & Espesor / Thickness (mm) & $\begin{array}{c}\text { Valor medio de la resistencia a tracción / } \\
\text { Mean tensile strength }\left(\mathbf{N} / \mathbf{m m}^{2}\right)\end{array}$ \\
\hline P3-1 & 21 & 0.039 \\
\hline P5-1 & 19 & 0.048 \\
\hline P3-2 & 16 & 0.074 \\
\hline P5-2 & 16 & 0.043 \\
\hline
\end{tabular}

a En todos los resultados la incertidumbre de los resultados es igual o menor a 0,001 N/mm² / In all results the uncertainly is $\leq 0.001 \mathrm{~N} / \mathrm{mm}^{2}$.

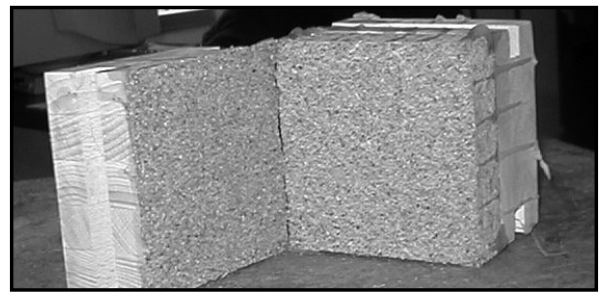

Figura 1. Probeta de tablero tras el ensayo de tracción.

Figure 1. Sample of chipboard after tensile strength test.

La tensión de fallo es muy baja pero similar a la tensión en probetas de panel sándwich aplicando el mismo proceso, ya que en ambos casos lo que se deteriora y evalúa es el tablero de partículas.

Este ensayo da una idea de la degradación que sufre el tablero que normalmente forma el paramento exterior de un panel sándwich y que no está condicionado por su calidad sino por la agresividad del ensayo al que se les somete. Debido al deterioro sufrido tras siete días, las probetas del ciclo de 28 días no se ensayaron porque quedaron completamente degradadas.

\subsection{Resultados de envejecimiento con variación de la duración del ciclo}

En este análisis solo se pudieron incluir los datos correspondientes a los fabricantes 1 y 2 ya que el deterioro sufrido en las muestras del fabricante 3 hizo imposible su ensayo. Los resultados obtenidos se pueden ver en la Tabla 8.

Asimismo, la pérdida de tensión que se produjo en los ciclos progresivos de 24 horas se presenta en la Figura 2.

Este estudio manifestó que la tensión de fallo tras el ciclo de un día puede reducirse entre un $12 \%$ y un $70 \%$, dependiendo del tipo de panel y fabricante de que se trate. Además, los valores de la tensión de fallo a partir del tercer día son menores a $0,1 \mathrm{~N} / \mathrm{mm}^{2}$, valor fijado como umbral que garantizaría una resistencia de aproximadamente $140 \mathrm{kN}$ para un panel de dimensiones estándar $2.400 \times 600 \mathrm{~mm}$.
The tensile strength was lower than, although similar to, that shown by the panel samples treated in the same fashion since in both cases the deteriorated feature was the chipboard face.

This test provides an idea of the degradation suffered by the external face board of these types of panel, and shows that it does not depend on the quality of the chipboard rather the procedure is too aggressive for determining the tensile strength. Given the deterioration suffered at just seven days, the samples subjected to the 28-day climatic testing cycle could not be tested because were completely deteriorated.

\subsection{Ageing results obtained when varying the length of the climatic testing cycle}

Table 8 shows the tensile strength results obtained with the products of different manufacturers when varying the length of the climatic testing cycle. Only data for the products of manufacturers 1 and 2 are provided; the products of manufacturer 3 were too deteriorated to be tested.

Figure 2 shows the loss of tensile strength over 24 hours intervals.

The results show that, depending on the type of panel sample and the manufacturer, tensile strength was reduced by $12-70 \%$ over each 24 hours period. The tensile strength values recorded from the third day were lower than $0.1 \mathrm{~N} / \mathrm{mm}^{2}$, the threshold that guarantees a resistance of $140 \mathrm{kN}$ for a panel of standard dimensions (2400x600 mm). 
Tabla 8 / Table 8

Resultados del ensayo de tracción tras envejecimiento con variación de la duración del ciclo. Results of tensile strength test following different climatic cycle time.

\begin{tabular}{|c|c|c|c|c|c|c|c|c|c|}
\hline \multirow{2}{*}{$\begin{array}{l}\text { Fabricante I } \\
\text { Manufacturer }\end{array}$} & \multirow{2}{*}{ Tipo panel / Type of panel sample } & \multicolumn{8}{|c|}{ Resistencia a la tracción / Tensile strength $\left(\mathrm{N} / \mathrm{mm}^{2}\right)$} \\
\hline & & Co & C1 & $\mathrm{C2}$ & 3 & C4 & C5 & C6 & C7 \\
\hline \multirow{5}{*}{ F1 / M1 } & $\begin{array}{l}\text { Partículas-XPS-madera cemento / } \\
\text { Chipboard-XPS-Wood-cement (CCM) }\end{array}$ & 0.260 & 0.083 & 0.066 & 0.035 & 0.015 & 0.034 & 0.022 & 0.025 \\
\hline & $\begin{array}{l}\text { Partículas-XPS-partículas / } \\
\text { Chipboard-XPS-Chipboard (CP) }\end{array}$ & 0.221 & 0.179 & 0.129 & 0.098 & 0.092 & 0.056 & 0.065 & 0.039 \\
\hline & $\begin{array}{c}\text { Partículas-XPS-yeso / } \\
\text { Chipboard-XPS-Plaster board (CY) }\end{array}$ & 0.146 & 0.087 & 0.025 & 0.077 & 0.059 & 0.082 & 0.061 & 0.022 \\
\hline & $\begin{array}{l}\text { Partículas-XPS-contrachapado / } \\
\text { Chipboard-XPS-Plywood (CCH) }\end{array}$ & 0.241 & 0.118 & 0.042 & 0.121 & 0.065 & 0.092 & 0.039 & 0.027 \\
\hline & $\begin{array}{c}\text { Partículas-XPS-friso / } \\
\text { Chipboard-XPS-Baseboard (CF) }\end{array}$ & 0.170 & 0.150 & 0.051 & 0.038 & 0.083 & 0.008 & 0.009 & 0.017 \\
\hline F2 / M2 & $\begin{array}{c}\text { Contrachapado-XPS-contrachapado / } \\
\text { Plywood-XPS-Plywood (TF) }\end{array}$ & 0.381 & 0.212 & 0.114 & 0.194 & 0.275 & 0.193 & 0.156 & 0.149 \\
\hline
\end{tabular}

a En todos los resultados la incertidumbre de los resultados es igual o menor a 0,004 N/mm² / In all results the uncertainly is equal or less than $0.004 \mathrm{~N} / \mathrm{mm}^{2}$.

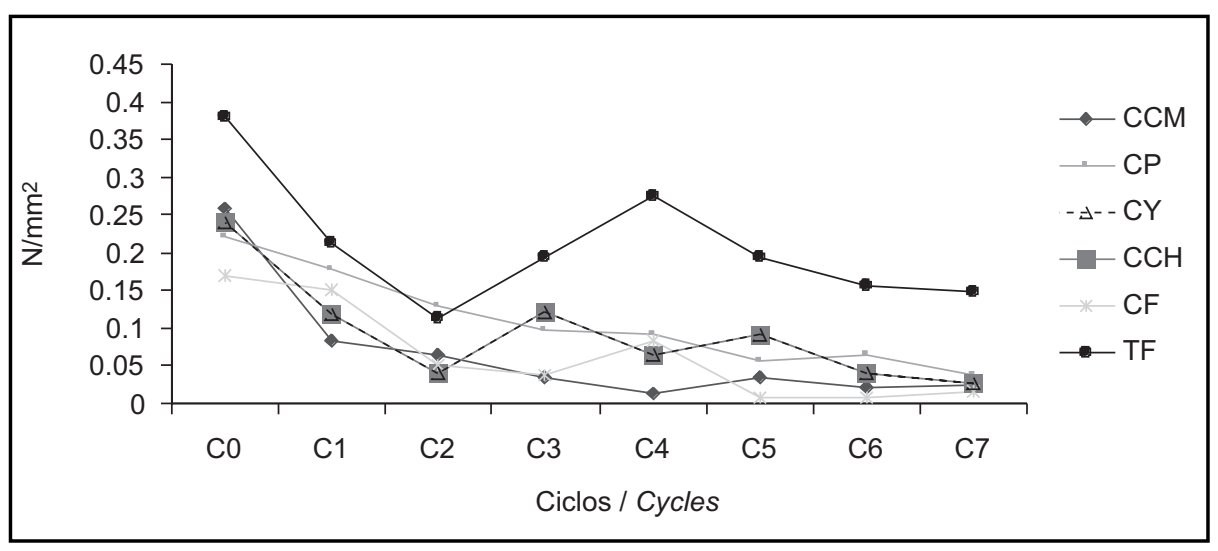

Figura 2. Variación de la resistencia a la tracción cada 24 horas Figure 2. Variation of tensile strength of every 24 hours.

En todos los casos en el que el tablero de partículas forma el paramento exterior del panel, las muestras se presentan muy deterioradas. El caso del fabricante 2 en el que los dos paramentos están formados por tableros contrachapados muestra el mejor comportamiento de este material frente al tablero de partículas, obteniéndose tensiones de fallo admisibles y la posibilidad de ejecutar el ensayo sin dificultad.

El hecho de que en algún caso no haya un comportamiento lineal descendente puede deberse a que se ensayó una única probeta por ciclo, lo cual introduce dispersión en los resultados.

\subsection{Resultados de la resistencia a la humedad según UNE-EN 321}

Los datos obtenidos de este ensayo para los distintos tipos de panel se presentan en la Tabla 9.
In all samples with a chipboard external face, the samples were very deteriorated. The plywood-faced sample of manufacturer 2 behaved better than those with chipboard faces; with these plywood-faced sample the test was completable and acceptable tensile strength was recorded.

The fact that in some cases a linear reduction in tensile strength over time was not seen might be explained by just one sample being tested per cycle. This could have introduced dispersion into the results.

\subsection{Moisture resistance determined following standard UNE-EN 321}

Table 9 shows the tensile strengths recorded after subjecting the samples to the testing described by standard UNE-EN 321. 
Tabla 9 / Table 9

Resultados del ensayo de tracción tras ciclos según UNE-EN 321. Results of tensile strength test after processing according to UNE-EN 321.

\begin{tabular}{|c|c|c|}
\hline $\begin{array}{c}\mathbf{N}^{\circ} \text { de ciclos I } \\
\text { Number of cycles }\end{array}$ & Tipo de panel / Type of panel sample & $\begin{array}{c}\text { Resistencia a la tracción / } \\
\text { Tensile strength }\left(\mathbf{N} / \mathbf{m m}^{2} \text { ) }\right.\end{array}$ \\
\hline \multirow{2}{*}{2} & Partículas-XPS-madera cemento / Chipboard-XPS-Wood-cement & 0.198 \\
\cline { 2 - 3 } & Partículas-XPS-friso / Chipboard-XPS-Baseboard & 0.088 \\
\cline { 2 - 3 } & Partículas-XPS-friso / Chipboard-XPS-Baseboard & 0.118 \\
\hline
\end{tabular}

a En todos los resultados la incertidumbre de los resultados es igual o menor a 0,002 N/mm² / In all results the uncertainly is $\leq$ than $0.002 \mathrm{~N} / \mathrm{mm}^{2}$.

De los resultados se puede derivar que el comportamiento del panel aguanta las condiciones de envejecimiento realizadas según UNE-EN 321, obteniéndose unas tensiones de fallo aceptables en el ensayo de tracción, superiores a $0,1 \mathrm{~N} / \mathrm{mm}^{2}$. Aun así, la metodología definida por esta norma no se sigue completamente, ya que se interrumpe en el segundo de los tres ciclos, por lo que con mucha probabilidad la tensión de fallo tras el tercer ciclo disminuiría y se asimilaría a las tensiones obtenidas tras los ensayos de durabilidad realizados según la ETAG-016.

\subsection{Resultados de durabilidad con lámina Tyvek ${ }^{\circ}$}

Los resultados de los ensayos a tracción realizados tras el ciclo de envejecimiento se muestran en la Tabla 10.

De las probetas que no se protegieron con lámina Tyvek $®$, tres no pudieron ensayarse por rotura previa al ensayo y otra presentó una tensión muy por debajo del
The results show that the tested samples withstood the conditions outlined by UNE-EN 321; acceptable tensile strengths were recorded (all above a $0.1 \mathrm{~N} / \mathrm{mm}^{2}$ ). However, the standard was not followed to the letter since no more than two immersion cycles were carried out. A third cycle would probably have reduced the tensile strength and the results would have been similar to those obtained when following the ETAG 016 procedure.

\subsection{Ageing results obtained with the Tyvek®-covered samples}

Table 10 shows the ageing results obtained with the Tyvek@-covered samples.

Three of the samples not protected by Tyvek® could not be subjected to the tensile strength test since they had already broken, and the other showed a tensile strength

Tabla 10 / Table 10

Resultados del ensayo de tracción tras ciclos de envejecimiento con lámina Tyvek®. Tensile strength after climatic testing cycles: Tyvek®-covered samples.

\begin{tabular}{|c|c|c|}
\hline $\begin{array}{c}\text { Código probeta / } \\
\text { Sample code }\end{array}$ & $\begin{array}{c}\text { Tensión de fallo / } \\
\text { Tensile strength (N/mm }{ }^{2} \text { ) }\end{array}$ & Observaciones / Observations \\
\hline F1-P1-C1 & 0.101 & Rotura del PUR / Breakage of the PUR \\
\hline F1-P2-C2 & 0.116 & Despegue del PUR en paramento inferior / Unsticking of the lower face from the PUR \\
\hline F1-P3-C7 & 0.100 & Despegue del PUR en paramento inferior / Unsticking of the lower face from the PUR \\
\hline F1-P4-C7* & 0.083 & Rotura del tablero de partículas / Breakage of the chipboard \\
\hline F1-P5-C1 & 0.133 & Despegue paramento inferior / Unsticking of the lower face board \\
\hline F1-P6-C2 & 0.179 & Despegue paramento inferior / Unsticking of the lower face board \\
\hline F1-P7-C7 & 0.060 & Despegue paramento inferior / Unsticking of the lower face board \\
\hline F1-P8-C7* & - & Rotura previa al ensayo / Breakage before tensile strength testing \\
\hline F2-P1-C1 & 0.286 & Despegue paramento exterior / Unsticking of the exterior face board \\
\hline F2-P2-C2 & 0.121 & Despegue paramento exterior / Unsticking of the exterior face board \\
\hline F2-P3-C7 & 0.159 & Despegue paramento exterior / Unsticking of the exterior face board \\
\hline F2-P3-C7* & - & Rotura previa al ensayo / Breakage before tensile strength testing \\
\hline F2-P5-C1 & 0.151 & Despegue paramento exterior / Unsticking of the exterior face board \\
\hline F2-P6-C2 & 0.192 & Despegue paramento inferior / Unsticking of the exterior face board \\
\hline F2-P7-C7 & 0.104 & Despegue paramento exterior / Unsticking of the exterior face board \\
\hline F2-P8-C7* & - & Rotura previa al ensayo / Breakage before tensile strength testing \\
\hline
\end{tabular}

* Probetas sin Tyvek $®$ / *Samples without Tyvek $\mathbb{R}$

a En todos los resultados la incertidumbre de los resultados es igual o menor a $0,003 \mathrm{~N} / \mathrm{mm}^{2}$ / In all results the uncertainly is $\leq 0.003 \mathrm{~N} / \mathrm{mm}^{2}$. 
umbral mínimo establecido en $0,1 \mathrm{~N} / \mathrm{mm}^{2}$. En los demás casos se observa un descenso en la tensión de fallo a tracción según avanza la duración del ciclo, cumpliendo con el umbral comentado excepto en uno de los casos (F1-P7-C7).

Como se puede observar, el panel que cuenta con núcleo de poliuretano inyectado (no encolado) presenta resultados satisfactorios $y$, aunque en la normativa queda fuera del alcance de este tipo de ciclo, da una idea de que el encolado del XPS a los paramentos en este ensayo sufre en exceso debido a la hidrosolubilidad que presen$\tan$ los adhesivos.

En la Figura 3 se presenta la evaluación por tipo de panel entre la tensión de fallo sin aplicación de ciclos de durabilidad (C0) y el ciclo de siete días (C7), incluyendo el porcentaje de caída de tensión que se produce entre ambos.

Se puede derivar que los valores de tensión de fallo tras el ciclo de siete días a $65^{\circ} \mathrm{C}$ de temperatura y $100 \%$ de humedad son, en todos los casos excepto el tipo Partículas-XPS-friso, superiores a $0,1 \mathrm{~N} / \mathrm{mm}^{2}$.

Igualmente se puede comprobar una vez más que, a pesar de la protección con lámina Tyvek, la humedad de este ensayo afecta en tal grado a los componentes de madera y los adhesivos utilizados que se producen caídas de hasta el $67 \%$.

\section{CONCLUSIONES}

1. El ensayo de durabilidad establecido en la ETAG-016 es aplicable para materiales situados en clase de uso 3, mientras que el panel sándwich de madera o derivado well below the $0.1 \mathrm{~N} / \mathrm{mm}^{2}$ acceptance threshold. In all other cases the tensile strength fell with the length of the climatic testing cycle, although an acceptable tensile strength was recorded except in one case (F1-P7-C7).

The sample with the injected PUR nucleus (not glued) showed satisfactory results. Although the methodology outlined does not apply to this kind of sandwich panel, this result is useful as a means of compare the great damage suffered by the XPS glued samples due to the water solubility of the adhesive used in their manufacture.

Figure 3 shows the change in tensile strength of each type of sandwich sample over no ageing (CO) and seven days of climatic testing (C7), as well as the percentage reduction in tensile strength suffered.

In all cases, the tensile strength after seven days was greater than $0.1 \mathrm{~N} / \mathrm{mm}^{2}$ except for the Chipboard-XPSBaseboard sample.

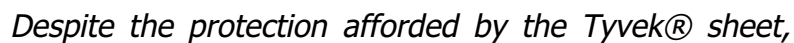
the humidity still affected the tensile strength of the panel components, with reductions of up to $67 \%$ in the original tensile strength recorded.

\section{CONCLUSIONS}

1. The durability test established in the ETAG-016 is applicable for materials located in use class 3, while the base-wood sandwich panel is designed to be

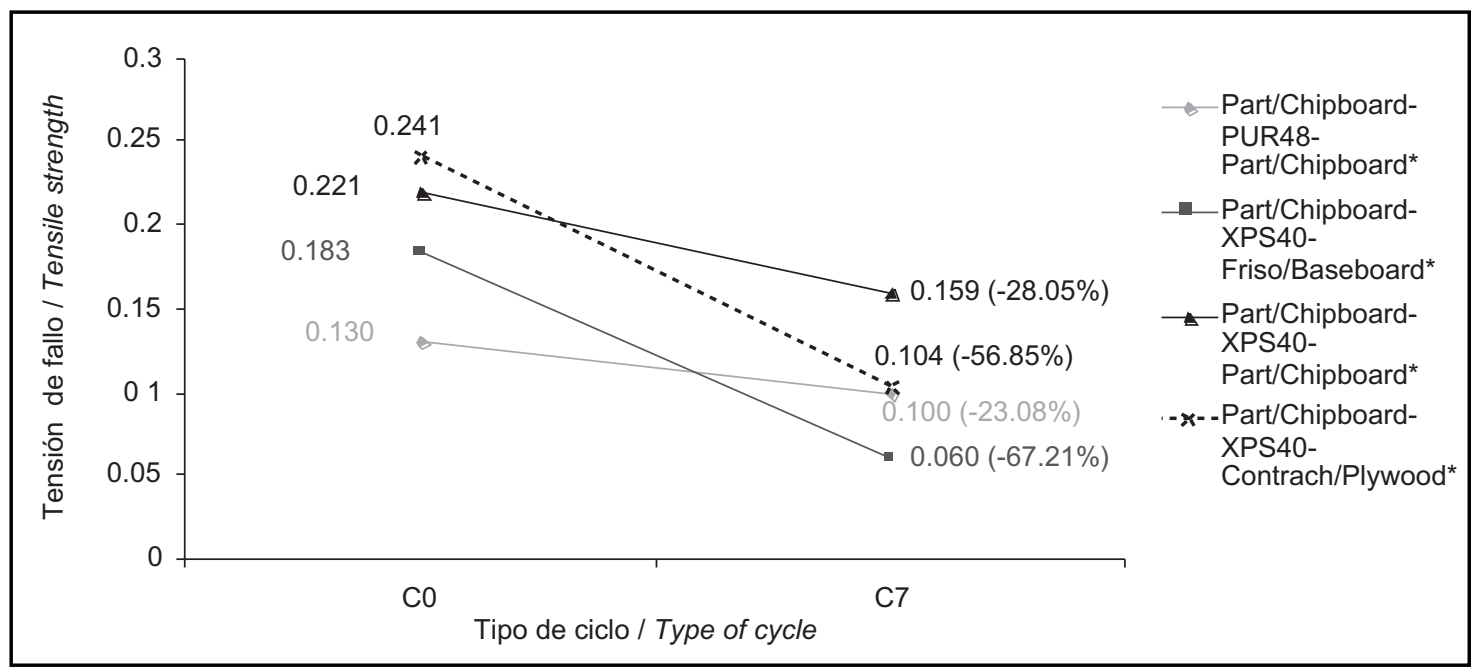

*Ver descripción de tabla 5. / * See the description of Table 5.

Figura 3. Comparación de las resistencias a la tracción entre el C0 y el C7 (con porcentaje de la caída de tensión) Figure 3. Tensile strength comparison between CO and C7 (including the percentage of tensile strength fall). 
de la madera está concebido para colocarse en clase de uso 2, por lo que se encuentra una incompatibilidad entre el uso real y el ensayo.

2. La aplicación de barniz sobre las muestras de panel sándwich de madera no mejora suficientemente el ensayo preceptivo para adoptarse como metodología de envejecimiento para este tipo de material.

3. La calidad de los tableros de partículas no es la causa del gran deterioro de las muestras tras el ensayo de la ETAG-016, sino las condiciones demasiado agresivas a las que se les someten.

4. La variación de la duración del ciclo demuestra que es inútil realizar ciclos de larga duración (más de siete días), ya que la disminución de la resistencia a la tracción no sigue produciéndose.

5. El uso de normativa asociada al estudio del envejecimiento en tableros (UNE-EN 321) indica que podría ser una alternativa al método actual, pero no queda claro, por lo que requiere un estudio de más profundidad.

6. De todos los ensayos realizados, el que mejor permite evaluar el envejecimiento de paneles sándwich de madera recreando el uso real de este material aportando tensiones de fallo aceptables es el realizado con recubrimiento de lámina Tyvek $₫$. Por eso se puede concluir que:

- Las condiciones de ensayo establecidas en la ETAG-016 es posible aplicarlas a probetas cubiertas por lámina Tyvek $®$ sin deteriorar por completo los paramentos.

- Los criterios de aceptación de la ETAG-016, $\mathrm{R} 28<40 \% R 0$ y $\mathrm{R} 7-\mathrm{R} 28 \leq 3$ (R0-R7), no han sido evaluados al haber sido imposible realizar el ciclo de 28 días debido el alto nivel de degradación que sufren las muestras.

- Después de la experiencia obtenida tras más de tres años realizando ensayos de este tipo según la guía ETAG-016, y teniendo en cuenta la metodología de instalación de los paneles sándwich, se estima que el ciclo de siete días supone un envejecimiento representativo de este producto sin necesidad de realizar ciclos de mayor duración.

- Igualmente, se considera que los criterios de aceptación o rechazo del panel deberían establecer una resistencia R7 mínima y una caída máxima entre R0 y R7. Investigaciones posteriores irán encaminadas a fijar estos umbrales y proponerlos como modificación de la ETAG-016 a la EOTA. placed in use class 2, so that there is an incompatibility between the real use and the established test.

2. The varnish applied to the wood-based sandwich samples did not sufficiently improve the prescribed test that might allow its use be adopted in the ageing testing of this type of material.

3. The quality of the chipboards is not the cause of the great deterioration of the samples following the ETAG 016 test, but rather the overly aggressive conditions to which they are subjected in this test.

4. The results associated with the different climatic testing cycle times show that it is pointless for these cycles to last any longer than seven days, since the reductions in tensile strength no further occur.

5. The results obtained using standard associated with the study of the ageing in boards (UNE-EN 321), suggest this might offer an alternative to the current method. However, further research is needed to confirm this.

6. Of all the testing performed, the method that best allowed the wood-based sandwich panels to be assessed in relation to ageing, which reflects their real installation and that provided acceptable tensile strength results, was that which involved their protection with Tyvek. Thus, it can be concluded that:

- The conditions of the ageing test outlined in ETAG 016 can be used with faces not completely deteriorated if the sample is protected by Tyvek®.

- The acceptance criteria of ETAG 016, $R 28<40 \% R 0$ and $R 7-R 28 \leq 3(R 0-R 7)$, were not assessed since no 28-day climatic testing cycle was possible owing to the deterioration of the samples.

- Bearing in mind our experience of over three years of testing according to ETAG 016, and the way in which these panels are usually installed, a seven-day climatic cycling period would seem sufficient.

- The acceptance/rejection criteria for panels should establish a minimum $R 7$ tensile strength and a maximum fall in tensile strength between $R O$ and R7. Work is being designed to set these thresholds which will be presented in proposed modifications to ETAG 016.

\section{BIBLIOGRAFÍA / BIBLIOGRAPHY}

(1) www.ietcc.csic.es (Instituto de Ciencias de la Construcción Eduardo Torroja).

(2) www.itec.cat (Instituto de Tecnología de la Construcción de Cataluña).

(3) Guía ETAG-016. Composite Light Weight Panels. Partes 1 y 2, noviembre de 2006. 
(4) www.eota.be (European Organisation for Technical Approvals).

(5) Código Técnico de la Edificación. Documento Básico SE-M Seguridad en Madera.

(6) Norma UNE-EN 14509:2007/AC: 2009. Paneles sándwich aislantes autoportantes de doble cara metálica. Productos hechos en fábrica. Especificaciones. AENOR.

(7) Peraza, F.; Arriaga, F.; Peraza, E.: Libro AITIM (2004), p. 252, Tableros de madera de uso estructural.

(8) www.finsa.es

(9) Maloney, T.: Modern particleboard and dry-process fiberboard manufacturing, Miller Freeman Inc. San Francisco (1993), p. 681.

(10) Deppe, H. J.; Ernst, K.: "Investigations on durability of gluing with carbamide and phenolic resins for particleboard", Holz als Rohund Werkstoff, vol. 24(7) (1966), pp. 285-300. doi:10.1007/BF02605292

(11) Norita, H.; Kojima, Y.; Suzuki, S.: "The aging effects of water inmersion treatments in wet-bending for standardized testing of wood panels", Journal of Wood Science, vol. 54(2) (2008), pp. 121-127. doi:10.1007/s10086-007-0919-3

(12) Niemz, P.; Petzold, H.; Haupl, P.: "Measurement and simulation of the moisture content changes in three-layer solid wood panels at different climates", Holz als Roh-und Werkstoff, vol. 61 (1) (2003), pp. 8-12. doi:10.1007/s00107-002-0343-8

(13) Kawasaki, T.; Zhang, M.; Kawai, S.: "Sandwich panel of veneer-overlaid low-density fibreboard", Journal of Wood Science, vol. 45(4) 1999, pp. 291-298. doi:10.1007/BF00833493

(14) River, B. H.:"Outdoor aging of wood-based panels and correlation with laboratory aging", Forest Product Journal, vol. 44(11-12) (1994), pp. 55-65.

(15) Barreto, C. C. K.; Pastorez, T. C. M.: "Resistance to artificial weathering of four tropical woods: the effect of the extractives", Ciencia forestal, vol. 19 (1-2) (2009), pp. 23-30.

(16) Edwin, L.; Ashraf, P. M.: "Assessment of biodeterioration of rubber wood exposed to field conditions. International biodeterioration an biodegradation", vol. 57(1) (2006), pp. 31-36. doi:10.1016/j.ibiod.2005.10.006

(17) De la Caba, K.; Guerrero, P.; Del Río, M.; Mondragón, I.: "Weathering behaviour of wood faced construction materials", Construction and building materials, vol. 21 (6) (2007), pp. 1288-1294. doi:10.1016/j.conbuildmat.2006.02.008

(18) Ghosh, S. C.; Militz, H.; Mai, C.: "Natural weathering of Scots Pine (Pinus sylvestris L.) boards modified with functionalised commercial silicone emulsions", Bioresources, vol. 4 (2) (2009), pp. 659-673.

(19) Turkulin, H.; Rajkovic, J.; Bogner, A.: "Structural effects of weathering on unprotected and painted wood", International conference surface properties and durability of exterior wood building (1999), Zagreb (Croacia).

(20) UNE-EN 312:2004: Tableros de partículas, Especificaciones, AENOR.

(21) UNE-EN 321:2002: Tableros derivados de la Madera, "Determinación de la resistencia a la humedad bajo condiciones de ensayo cíclicas", AENOR. 